\author{
Ewa Wanda Maruszewska \\ University of Economics in Katowice \\ e-mail: ewa.maruszewska@ue.katowice.pl \\ ORCID: 0000-0003-0461-4133
}

\title{
PERCEPTION OF DISCRETIONARY ACCOUNTING FOR BUSINESS COMBINATIONS. AN ETHICAL APPROACH
}

DOI: $10.15611 /$ pn.2020.8.07

JEL Classification: M40, M41, G34, G41

(C) 2020 Ewa Wanda Maruszewska

This work is licensed under the Creative Commons Attribution-ShareAlike 4.0 International License. To view a copy of this license, visit http://creativecommons.org/licenses/by-sa/4.0/

Quote as: Maruszewska, E. W. (2020). Perception of discretionary accounting for business combinations. An ethical approach. Prace Naukowe Uniwersytetu Ekonomicznego we Wroctawiu, 64(8).

\begin{abstract}
This paper investigated how Polish students of accounting perceive the lack of precision of accounting regulations for business combinations. It was hypothesized and confirmed that young accountants show the propensity to exercise discretion in the accounting for business combinations to the detriment of faithfulness of financial information. The study is based on a survey questionnaire of 91 accounting faculty students. The responses suggest that the unethical usage of flexibility in accounting is justified by many situational factors. Although it is difficult to generalize the results, the findings are useful in demonstrating how ethical enhancement is needed in both education and accounting regulations.
\end{abstract}

Keywords: accounting ethics, business combinations, discretionary accounting.

\section{Introduction}

It is a well-known fact that accounting is not a neutral instrument of economic recording and measurement because remote settings of business operations locate accountants in a broader social context (Napier, 2006, p. 462). Hence, being aware that accounting allows for management discretion, investors do react to different information content of financial reports. On that basis there is a large number of studies that investigate accounting for business combinations, as in recent years historical cost was substituted by fair value in accounting for these transactions, creating space for discretionary accounting. 
The studies mentioned above are consistent with the findings that the items presented in the statement of a company's financial position, among them goodwill and intangibles acquired in a business combination, are regarded as useful by stockmarket investors as they serve as indicators of the firm's future profit-making potential (Hirschey and Richardson, 2002, p. 187; Jifri and Citron, 2009, p. 137; Kimbrough, 2007, p. 24; Zhang and Zhang, 2017). There is also a contrasting finding of Shalev $(2009$, p. 265) which suggests that investors fail to immediately incorporate information content of business combination disclosure level into their information set and that investors are quicker to react to firms with a negative abnormal disclosure. Knauer and Wöhrmann (2016, p. 446), also using a business combination setting, found that if management discretion is high because of the low level of legal protection, investors react in a more negative way to announcements of unexpected goodwill write-offs. Alongside the research concentrating on the investors' reactions to information content, there is also a group of studies showing that economic and other incentives influence the decisions taken by preparers of financial reports in the scope of business combinations. For example, Hamberg, Paananen and Novak found that economic incentives determine the choice related to the final measurement of goodwill disclosed at the initial adoption of acquisition accounting regulations (Hamberg, Paananen, and Novak, 2011, p. 284).

Two research questions were formulated on the basis of prior research which stresses the possibility of discretionary accounting for business combinations and on the outcomes of studies presented by Polish researchers investigating business combinations (Grzybek and Maruszewska, 2016; Grzybek, Maruszewska, PapajWlisłocka, and Strojek-Filus 2020; Janowicz, 2016; Luty, 2016; Remlein, 2009; Toborek-Mazur, 2005):

(1) how Polish students of accounting perceive the lack of precision of accounting regulations for business combinations, and

(2) whether they show the propensity to use discretionary accounting in the scope of the initial measurement of assets acquired in business combinations.

The study adopted a decision-making task as the research instrument, namely a questionnaire to measure the respondents' propensity to make a decision based on imprecise accounting regulations in order to create favourable financial picture of the entity. In addition, a scale semantic differential was administered to study comprehension of discretionary accounting. A 5-point and 7-point Likert scale was used for both parts of the instrument.

This paper contributes to the body of knowledge on accounting for business combination by highlighting the need for an ethical approach for both practitioners and accounting regulators. Some of the practitioners are inclined to use accounting for business combinations to create a favourable picture which may result in the acceptance of manipulated financial reports. Furthermore, it indicates that prevailing compliance with the literal wording of the law eliminates the underlying foundations of accounting built on the assumption of truth. 
The remainder of this paper is as follows: Section 2 provides the background for discretionary accounting in the scope of business combinations and develops the hypothesis. Section 3 describes the method, while Section 4 presents the results, and The concluding remarks are provided in Section 5.

\section{Discretionary choices in accounting for business combinations}

Managerial discretion in accounting for business combinations refers mainly to:

a) the choice of accounting method in the case of business combinations under common control (Janowicz, 2014, 2017),

b) estimates used for fair value measurement (especially when actual market is not used for the valuation purposes) in the case of the acquisition method (Giner and Pardo, 2015; Seetharaman, Sreenivasan, Suda, and Yee, 2006),

c) goodwill and other intangibles measurement together with impairment (Lee, 2011; Vance, 2010),

d) purchase price allocations (Paugam, Astolfi, and Ramond, 2015).

Not only do the above-mentioned issues comprise an area of relatively large managerial discretion, they also characterize the key ethical issues that accounting practitioners face when dealing with business combinations. The association between ethics and the possibility of engaging in earnings management has been widely discussed in the literature. It was pointed out that those who prepare reports do not necessarily violate the law but use flexibility inherent in the preparation of financial statements to satisfy their own interests, rather than communicate the financial position of their companies (Choi and Pae, 2011; Maruszewska and Kołodziej, 2015; Nowak, 2018).

Furthermore, prior research related to decision-making describes a broad range of incentives that influence the choices made by accountants to the detriment of the faithfulness of financial information (Kunz and Pfaff, 2002; Libby, Bloomfield, and Nelson, 2002; Modell, Vinnari, and Lukka, 2017). Moreover, behavioural accounting research provides evidence that there is no need for both the characteristics of agency framework (i.e. conflict of interest and information asymmetry) in order for professionals to make unethical decisions. The occurrence of just one of the two characteristics describing the agency theory already threatens the professionalism of decision makers (Boedker and Chua, 2013).

The following hypothesis was formulated based on the literature review showing the complexity and imprecision of accounting for business combinations and decision-making studies in ambiguous situations: the perception of discretionary accounting for business combinations accepts a favourable picture to the detriment of the faithfulness of financial information. 


\section{Study design}

The study was conducted among part-time graduate students who completed the "Accounting for business combinations" course. Up-to-date knowledge in the field was the most important characteristic of the respondents, followed by their experience. The study was conducted in the form of a questionnaire in which the respondents made a choice in a described hypothetical situation of an entity obliged to comply with the Accounting Act that is in force in Poland at present. The study used a 5-point Likert scale and semantic differential to study their understanding of discretionary accounting.

The presented situation referred to two problems: the fair value valuation required by the acquisition method, and the selection of one of two methods (pooling-of-interests versus acquisition method) allowed by the Polish Accounting Act. Both situations were presented to the respondents in the same manner:

- information on the role of the respondent acting as a chief accountant as well as on the obligation to make a decision and the responsibility for it,

- a description indicating the details of the problem:

- the intangible character of the acquired assets and the possibility to measure them (in fair value) in high or low values using discretionary accounting (scenario \#1),

- no clear boundary in legislation between the obligatory use of each of the two methods of accounting for business combinations due to the entity's ownership situation within the unregulated area (scenario \#2),

- an indication of the consequences in the form of a decline or an increase in the financial results,

- information that the chief accountant decides autonomously, and that the independent auditor has little chance to question the decision made.

In the following part of the questionnaire the participants were asked to determine their propensity to make a decision that uses imprecise accounting regulations on 'window-dressing' for the purposes of the bank loan application. When making such a decision, the subjects would use flexible accounting regulations in a way that deteriorates the reliability of financial information and at the same time helps in achieving the short-term goal, i.e. increasing the value of assets that would be under examination of the bank. Furthermore, the respondents were asked to judge the decision using the semantic scale. Their judgments were aimed at accepting and justifying the decision.

The study covered 91 part-time students of accounting at two universities in Poland, who were generally of 21 to 31 years of age $(n=91 ; 94 \%)$. The oldest respondent was 50 years old; $47 \%$ had previous accounting education (college or high school; $n=43$ ), while other 25 respondents declared having economic education $(27 \%)$ and $75 \%(n=68)$ indicated that they already had practical experience strictly in accounting positions. Although most of the respondents declared experience of 
below 5 years $(n=62 ; 68 \%)$, a large number of them occupied a mid-level position ( $n=47 ; 52 \%)$, while only 7 respondents $(8 \%)$ held a top managerial position; $47 \%$ indicated that they worked in micro enterprises $(n=43)$, and $17 \%$ in a small enterprise $(n=15)$, whereas $11 \%$ gained professional experience in medium entities $(n=10)$, while $15 \%$ in large ones $(n=14)$.

The presented characteristics of the respondents set the limitations of the study. The findings of the study cannot be generalized to all accounting professionals, in particular to bookkeepers with many years of experience. As the scenarios dealt with a very specific accounting situation that does not occur in every entity, the up-todate and detailed knowledge was the main determinant of the respondents in the survey. Yet the results of the study can serve as the basis for analysing the perception of discretionary accounting regulations that influence the valuation of assets and liabilities.

\section{Results}

Descriptive statistics (Table 1) show the propensity to make:

- a decision that creates a favorable picture of the valuation of the assets (increase in value) versus

- a decision that ensures the faithfulness of the financial information regardless of the consequences in the form of lowering the amount of assets disclosed in the statement of financial position.

Table 1. Descriptive statistics on the propensity to make decision that ensures the faithfulness of the accounting information

\begin{tabular}{|l|c|c|}
\hline Descriptive analysis/Scenario & Scenario \#1 & Scenario \#2 \\
\hline Number of answers & 46 & 45 \\
\hline Median & 3.0 & 2.0 \\
\hline Minimum & 1 & 1 \\
\hline Maximum & 5 & 5 \\
\hline Standard deviation & 1.191 & 1.078 \\
\hline Mode & 2.0 & 2.0 \\
\hline Average & 2.847 & 2.466 \\
\hline
\end{tabular}

Scale 1-5, where 1 means 'I am definitely willing to make a decision that distorts accounting information' and 5 indicates 'I am definitely willing to make a decision that ensures the faithfulness of the accounting information'.

Source: own elaboration.

The results indicate that around a quarter of the respondents was undecided (scenario \#1 $n=11 ; 24 \%$; scenario \#2 $n=11 ; 24 \%$ ). Apart from this, most respondents showed high propensity to distort accounting data. In scenario \#1 20 subjects (44\%) 
indicated "1" or " 2 " while among those who read scenario \#2, 25 subjects pointed to the same answer (54\%). No statistically significant differences were found between those respondents who were to make a decision in scenario \#1 compared to scenario $\# 2(t(89)=1.198 ; p=.114)$.

In the second part of the survey (Table 2), the respondents were to explain their judgments about the choice that resulted in the distortion of the value of assets. The analysis of the results obtained on a semantic scale (using a 7-point scale) was preceded by the reliability verification, which was carried out based on Cronbach's Alpha ratio separately calculated for scenario \#1 and scenario \#2. In both cases the reliability was confirmed, resulting in high rates, i.e. for scenario $1 \alpha=.748$ and for scenario 2 $\alpha=.738$.

Table 2. Descriptive statistics on the study's semantic scale

\begin{tabular}{|c|c|c|c|c|c|c|c|c|c|c|c|}
\hline \multirow{2}{*}{$\begin{array}{l}\text { Defined judgment about } \\
\text { the decision that distorts } \\
\text { accounting information }\end{array}$} & \multicolumn{5}{|c|}{$\begin{array}{l}\text { Scenario \#1 } \\
\quad n=46\end{array}$} & \multicolumn{5}{|c|}{$\begin{array}{c}\text { Scenario \#2 } \\
\quad n=45\end{array}$} & \multirow{2}{*}{$\begin{array}{c}\text { Mann- } \\
\text {-Whitney } \\
\text { Test U } \\
\alpha=.05\end{array}$} \\
\hline & 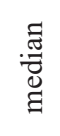 & $\cdot \Xi$ & $\stackrel{\underset{\mathfrak{U}}{\Xi}}{\Xi}$ & 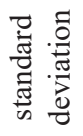 & $\begin{array}{l}\mathbb{Z} \\
\Xi \\
\Xi\end{array}$ & 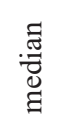 & 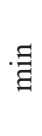 & 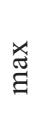 & 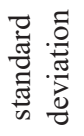 & $\begin{array}{l}\mathscr{8} \\
\stackrel{\Xi}{\Xi}\end{array}$ & \\
\hline $\begin{array}{l}\text { Culturally acceptable (1) / } \\
\text { Culturally unacceptable (5) }\end{array}$ & 3.0 & 1 & 6 & 1.64 & 2 & 3.0 & 1 & 6 & 1.37 & 3 & .760 \\
\hline $\begin{array}{l}\text { Individually acceptable (1) / } \\
\text { individually unacceptable (5) }\end{array}$ & 2.0 & 1 & 7 & 1.64 & 1 & 3.0 & 1 & 6 & 1.44 & 3 & .495 \\
\hline $\begin{array}{l}\text { Justified by the firm's situation } \\
\text { (1) / Unjustified ... (5) }\end{array}$ & 2.0 & 1 & 5 & 1.16 & 1 & 2.0 & 1 & 7 & 1.41 & 1 & .413 \\
\hline $\begin{array}{l}\text { Bringing benefits to the entity } \\
\text { (1) / Causing damage to the } \\
\text { entity (5) }\end{array}$ & 2.0 & 1 & 5 & 1.21 & 1 & 2.0 & 1 & 7 & 1.43 & 1 & .681 \\
\hline $\begin{array}{l}\text { Economically justified (1) / } \\
\text { Economically unjustified (5) }\end{array}$ & 2.0 & 1 & 7 & 1.34 & 2 & 3.0 & 1 & 6 & 1.21 & 3 & .613 \\
\hline Fair (1) / Unfair (5) & 3.0 & 1 & 7 & 1.75 & 3 & 3.0 & 1 & 6 & 1.43 & 4 & .056 \\
\hline Ethical (1) / Unethical (5) & 5.0 & 1 & 7 & 1.73 & 4 & 4.0 & 1 & 7 & 1.42 & 4 & .056 \\
\hline
\end{tabular}

Source: own elaboration.

No statistically significant differences were found between the judgments of respondents making decisions in scenario \#1 and those making decisions in scenario \#2. A strong conviction can be observed among both groups of subjects that the behaviour distorting accounting information is culturally acceptable $(n=56$; $62 \%$ ). A similar result was obtained when the respondents were judging individual acceptance of the decision behind which there is unclear, non-substantive evidence ( $n=61 ; 67 \%)$. In other words, according to the respondents it can be acceptable for an individual to make a decision that uses loopholes in the law and that results in 
'window-dressing'. The above finding is also confirmed by the answers given to the next three questions, as:

- most subjects were convinced that such a behaviour can be justified by the situation of the entity $(n=73 ; 80 \%)$,

- the same number $(n=73 ; 80 \%)$ expressed the opinion that the decision undermining faithfulness of financial data may bring benefits to the entity, and

- even more respondents justified the decision with economic reasons $(n=76 ; 84 \%)$. Furthermore, most of the subject expressed an opinion that making a decision resulting in 'window-dressing' is fair $(n=50 ; 55 \%)$. The results also indicated that most subjects were not able to express an opinion whether making a decision lowering the reliability of accounting information is ethical or unethical ( $n=27 ; 30 \%$ undecided).

In addition, the results indicated that:

(1) among those who completed a decision task in \#1 scenario:

- those with previous accounting and broader economic education were more convinced that the decision distorting accounting data can be economically justified $(\chi 2(24, N=46)=38.428, p=.031)$;

(2) among those who accomplished a decision task in \#2 scenario:

- the judgment about the fact that decisions lowering the reliability of the accounting data can be individually acceptable was highest among the respondents aged 21 to $25\left(\chi^{2}(40, N=45)=58.180, p=.031\right)$.

When analyzing the whole group of respondents $(n=91)$, it was found that the judgment that other accountants would base their decision on previous practice was the weakest among those with experience of over 10 years $\left(\chi^{2}(16, N=91)\right.$ $=50.419, p<0,001)$. It was easier for low and middle-level employees to accept that decisions resulting in distorted financial data are culturally acceptable $\left(\chi^{2}(15\right.$, $N=85)=25.589, p=.043$ ).

In order to examine in-depth the judgments of the subjects, further explanations in the legal, organizational and professional sphere were discussed in groups of four respondents, assigned randomly. The qualitative analysis of the textual opinions of decision-making in accounting for business combinations revealed that the most frequently cited arguments referred to the productive use of loopholes and the flexibility of accounting law to benefit the company. Moreover, the respondents indicated that the low risk that auditor would question the decision should also be taken into account. In the organizational sphere, the subjects argued that using loopholes to the advantage of the entity would result in good relations between the accountant and the management.

\section{Conclusion}

The main finding of the study is that the respondents representing present and future accounting professionals already educated in financial reporting showed a high propensity to distort accounting information. The tendency to be unprofessional 
was investigated in the scope of business combination transactions. Prior research and practice showed that these transactions are used for earnings management (Giner and Pardo, 2015; Shalev, Zhang, and Zhang, 2010). The propensity to use business combinations for creating a favourable picture of an entity may result from the opinion that it is acceptable to take advantage of the flexibility of accounting regulations, as long as the application of the law is in accordance with its literal meaning. This assumption is indicated by the results of the second part of the survey. The respondents expressed the opinion that such a behaviour can be justified by the situation (e.g. economic) of the entity and it can be beneficial to the entity.

Most respondents were convinced that such behaviour is fair and had no opinion about the ethical dimension of the situation. The above finding, together with the high acceptance to justify such behaviour, shows that the ethical foundations of accounting have less (if any) significance for its practitioners. The prevailing compliance with the literal wording of the law eliminates the underlying foundations of accounting built on the assumption of truth.

To sum up, the perception of the flexibility of accounting regulations in the scope of business combinations allows for decision-making as stated in the saying: "what is not prohibited, is allowed". Such a viewpoint destroys the ethical foundation of accounting, which has no explicit references in any paragraph of the Accounting Act, except for the true and fair view principle. In addition, the high propensity to make unethical use of discretionary accounting, and the many accepted justifications for such behaviour, indicate that the ethical dimension requires enhancement by law. Therefore it can be concluded that the hypothesis was confirmed, i.e. the perception of discretionary accounting for business combinations accepts a favourable picture to the detriment of faithfulness of financial information. Future research should thus be carried out from the perspective of regulators, and the professional developments of practicing accountants and involve certain cultural, motivational and personal issues affecting dysfunctional, unethical practices in accounting for business combinations.

\section{References}

Boedker, Ch., and Chua, W. F. (2013). Accounting as an affective technology: A study of circulation, agency and entrancement. Accounting, Organizations and Society, (38), 245-267.

Giner, B., and Pardo, F. (2015). How ethical are managers' goodwill impairment decisions in Spanish-listed companies? Journal of Business Ethics, (132), 21-40.

Grzybek, O., and Maruszewska, E. W. (2016). Treść ekonomiczna wartości firmy i ujawnienia w tym zakresie - analiza sprawozdań finansowych polskich spółek. Studia Ekonomiczne, (300), 88-97.

Grzybek, O., Maruszewska, E. W., Papaj-Wlisłocka E., and Strojek-Filus, M. (2020). Recognition of identifiable assets in business combinations. The case of Poland. In: Education excellence and innovation management: A 2025 vision to sustain economic development during global challenges. (Proceedings of the 35th International Business Information Management Association Conference (IBIMA), 1-2 April 2020 Seville, Spain), 11342-11353.

Hamberg, M., Paananen, M., and Novak, J. (2011). The adoption of IFRS 3: The effect of managerial discretion and stock market reaction. European Accounting Review, 20(2), 263-288. 
Hirschey, M., and Richardson, V. J. (2002). Journal of Accounting and Public Policy, (21), 173-191.

Janowicz, M. (2014). Metody księgowego rozliczenia połączeń pod wspólną kontrolą w praktyce polskich spółek publicznych sporządzających sprawozdania finansowe zgodnie z MSSF. Finanse, Rynki Finansowe, Ubezpieczenia, (71), 97-108.

Janowicz, M. (2016). Ujawnienia na temat połączenia jednostek gospodarczych w kontekście oceny jego charakteru ekonomicznego, Studia Oeconomica Posnaniensia, 4(11), 107-121.

Janowicz, M. (2017). Business combinations under common control in International Financial Reporting Standards - is authoritative accounting guidance needed? Zeszyty Teoretyczne Rachunkowości, 93(149), 97-111.

Jifri, K., and Citron, D. (2009). The value-relevance of financial statement recognition versus note disclosure: evidence from goodwill accounting. European Accounting Review, 18(1), 123-140.

Kimbrough, M. D. (2007). Do investors rely on purchase price allocation disclosure? Working Paper Harvard Business School, 1-46.

Knauer, T., and Wöhrmann, A. (2016). Market reaction to goodwill impairment. European Accounting Review, 25(3), 421-449.

Kunz, A. H., and Pfaff, D. (2002). Agency theory, performance evaluation, and the hypothetical construct of intrinsic motivation. Accounting, Organizations and Society, (27), 275-295.

Lee, Ch. (2011). The effect of SFAS 142 on the ability of goodwill to predict future cash flows. Journal of Accounting and Public Policy, (30), 236-255.

Libby, R., Bloomfield R., and Nelson, M. W. (2002). Experimental research in financial accounting. Accounting, Organizations and Society, (27), 775-810.

Luty, P. (2016). Struktura aktywów spółki a struktura kapitału w połączeniach polskich jednostek gospodarczych w latach 2002-2013. Finanse, Rynki Finansowe, Ubezpieczenia, 1(79), 595-606.

Maruszewska, E. W., and Kołodziej, S. (2015). The ethical and psychological approach to high quality financial reports, 21-38. In I. Boitan, and Barbu T. (eds.) Financial industry at the crossroads between current practices and ethical virtues. Ukraine: Taadler Publishing House.

Modell, S., Vinnari, E., and Lukka, K. (2017). On the virtues and vices of combining theories: the case of institutional and actor-network theories in accounting research. Accounting, Organizations and Society, 60, 62-78.

Napier, Ch. J. (2006). Accounts of change: 30 years of historical accounting research. Accounting, Organizations and Society, 31, 445-507.

Nowak, M. (2018). Polish researchers' view on accounting ethics. Meta-analysis of domestic monographs. Prace Naukowe Uniwersytetu Ekonomicznego we Wrocławiu, (506), 93-104.

Paugam, L., Astolfi, P., and Ramond, O. (2015). Accounting for business combinations: Do purchase price matter? Journal of Accounting and Public Policy, (34), 362-391.

Remlein, M. (2009). Metoda nabycia a metoda łączenia udziałów w procesie łączenia jednostek gospodarczych - rozwiązania krajowe i międzynarodowe. Zeszyty Teoretyczne Rachunkowości, 49(105), 213-223.

Seetharaman, A., Sreenivasan, J., Suda, R., and Yee, T. Y. (2006). Managing impairment of goodwill. Journal of Intellectual Capital, 7(3), 338-353.

Shalev, R. (2009). The information content of business combination disclosure level. The Accounting Review, 84(1), 239-270.

Shalve, R., Zhang, I., and Zhang, Y. (2010). CEO compensation and fair value accounting: evidence from purchase price allocation. Retrieved November 20, 2029 from http://ssrn.com/abstract=1600903

Toborek-Mazur, J. (2005). Różnice w prezentacji połączeń spółek według polskiego i międzynarodowego prawa bilansowego. Zeszyty Teoretyczne Rachunkowości, 28(84), 111-123.

Vance, D. E. (2010). Return on goodwill. The Journal of Applied Business Research, 26(2), 93-103.

Zhang, I. X., and Zhang, Y. (2017). Accounting discretion and purchase price allocation after acquisitions. Journal of Accounting, Auditing and Finance, 32(2), 241-270. 


\section{POSTRZEGANIE UZNANIOWYCH REGULACJI RACHUNKOWOŚCI W OBSZARZE POŁĄCZEŃ JEDNOSTEK. PERSPEKTYWA ETYCZNA}

Streszczenie: W artykule omówiono postrzeganie nieprecyzyjnych regulacji rachunkowości w obszarze rachunkowości połączeń jednostek przez polskich adeptów rachunkowości. Potwierdzono hipotezę, że młodzi praktycy rachunkowości wykazują dużą skłonność do wykorzystywania uznaniowości rachunkowości połączeń ze szkodą dla rzetelności informacji finansowych. Dociekania są oparte na badaniu kwestionariuszowym przeprowadzonym wśród 91 studentów studiów niestacjonarnych na kierunku rachunkowość. Wyniki sugerują, że nieetyczne stosowanie prawa o rachunkowości usprawiedliwiane jest przez szereg czynników sytuacyjnych. Choć rezultaty badania nie powinny być uogólniane, wyraźnie wskazują na konieczność wzmocnienia etycznego w obszarze zarówno edukacji przyszłych służb rachunkowości, jak i prawa o rachunkowości.

Słowa kluczowe: etyka w rachunkowości, rachunkowość połączeń, uznaniowość decyzji w rachunkowości. 